\title{
Temperature, organic matter, and the control of bacterioplankton in the Neuse River and Pamlico Sound estuarine system
}

\author{
Benjamin L. Peierls*, Hans W. Paerl \\ University of North Carolina at Chapel Hill, Institute of Marine Sciences, 3431 Arendell Street, Morehead City, \\ North Carolina 28557, USA
}

\begin{abstract}
A 4 yr, spatially extensive study of the Neuse River and Pamlico Sound estuarine system, North Carolina, was used to evaluate the temporal patterns and bottom-up controls of the resident bacterioplankton community. This meso- to eutrophic estuarine system had high concentrations of dissolved and particulate organic matter and supported an active and abundant phytoplankton community. Temporal analysis of bacterioplankton productivity (BP) revealed a strong seasonal pattern, similar to water temperature. Comparisons of BP and several environmental variables grouped by season and year showed little correspondence between the bacteria and either river discharge or organic matter at either scale. Temperature explained about half of the variation in BP data, but without any obvious threshold in the semi-log temperature-productivity relationship, implying the absence of a shift to substrate limitation at higher temperatures. The temperature effect varied in space and was lower at the freshwater station, suggesting differential substrate availability or the presence of a different resident microbial community. Proxies for bacterial substrates, including dissolved organic carbon, particulate organic nitrogen, and chlorophyll $a$, improved the predictive power in multiple regression models, but at least one-third of the variation in BP remained unexplained. The regression models differed by station group, further highlighting the possible difference in biota and/or resources between the freshwater and brackish sites.
\end{abstract}

KEY WORDS: Bacterioplankton · Productivity $\cdot$ Estuary $\cdot$ Temperature $\cdot$ Organic matter Resale or republication not permitted without written consent of the publisher

\section{INTRODUCTION}

Over the last several decades, bacterioplankton productivity (BP) determinations have become routine in the study of pelagic microbial communities, despite methodological limitations (Gasol et al. 2008). These rates, along with measurements of respiration and specific growth, can be used as indicators of microbial loop activity and overall carbon cycling. Estuaries are some of the most fertile and ecologically significant aquatic ecosystems on Earth and yet are also among the most anthropogenically stressed (Day et al. 1989). Understanding microbial processes and carbon cycling in these systems is critically important in the face of regional and global change.
One of the difficulties in understanding BP in estuaries is the number of possible controlling factors combined with the inherent physical and biogeochemical complexity of these systems. Many studies of estuarine BP have reported on the importance of temperature and the supply of dissolved organic carbon and inorganic nutrients in controlling BP (Hoch \& Kirchman 1993, Shiah \& Ducklow 1994a,b, Goosen et al. 1997, Revilla et al. 2000, Apple et al. 2006). Of these, temperature seems to dominate as a driver of productivity, especially since estuarine systems typically have a plentiful supply of organic matter. Temperature and substrate are also known to interact in the control of BP (Pomeroy \& Wiebe 2001). In many systems there appears to be a threshold response, where tempera- 
ture control gives way to substrate limitation (Shiah \& Ducklow 1994a, Apple et al. 2006), although this is not always the case (Hobbie \& Cole 1984, Staroscik \& Smith 2004).

Estuarine BP has been relatively well studied when compared to other marine ecosystems (Ducklow \& Shiah 1993), but much of the research has been limited in time and space. Individual estuaries are unique systems based on their geomorphic, hydrologic, climatic, and watershed characteristics, and it remains a challenge to make generalizations about the patterns and controls of estuarine BP (Wright \& Coffin 1983, MCManus et al. 2004). The Neuse River and Pamlico Sound (NRPS) estuarine system (North Carolina, USA) has witnessed several decades of basic and applied research aimed at combating water quality problems associated with excessive anthropogenic nutrient overenrichment (Paerl et al. 2006a,b), but little is known about BP dynamics. Christian et al. (1984) examined some aspects of the bacterioplankton community in the Neuse River, but that study was limited to the summer of $1 \mathrm{yr}$. The present study examined the temporal variability of BP in the NRPS system over a 4 yr period with a focus on the effects of temperature. Patterns of BP were compared to the temporal variation of co-occurring environmental and biological variables. While temperature was hypothesized to be the dominant controlling factor of $\mathrm{BP}$, an additional objective was to establish what other bottom-up factors most strongly influence and hence help predict overall bacterioplankton activity.

\section{MATERIALS AND METHODS}

Stations and sample collection. Most of the sampling for bacterioplankton was done in parallel with field measurements and water collection that were part of a long-term water quality monitoring program (ModMon, www.unc.edu/ims/ neuse/modmon/). From 2002 to 2005, biweekly to monthly trips were made to the estuary, where each trip included stations in either the Neuse River or Pamlico Sound (Fig. 1). The 8 stations, 4 in each region, were chosen to span the known salinity and trophic gradients.

Basic water quality characteristics were collected at each station using a YSI 6600 sonde configured to measure temperature and salinity. Sensors were calibrated prior to each sampling date and readings were taken just below the water surface. Daily mean river dis- charge data came from USGS Gage No. 02091814 near Ft. Barnwell, North Carolina (waterdata.usgs.gov/nc/ nwis). At each station, water was collected from the surface by submerging cleaned (dilute acid and deionized water) and sample-rinsed polyethylene containers 10 to $20 \mathrm{~cm}$ below the water surface. All samples were kept covered during transport to the laboratory.

Chemistry and phytoplankton. The methods for organic matter, nutrients, and phytoplankton variables are described in detail in Peierls et al. (2003), and only a brief summary will be given. Dissolved organic carbon (DOC) was measured on glass fiber (GF/F) filtrate using high temperature catalyzed oxidation coupled with infrared analysis. Dissolved organic nitrogen (DON) was the difference between total dissolved $\mathrm{N}$ (TDN) and dissolved inorganic $\mathrm{N}$ (DIN; sum of nitrate + nitrite and ammonium), both measured by flow injection analysis (after inline digestion for TDN) on glass fiber filtrate; dissolved phosphate was measured with the same flow injection analysis system. Particulate organic C (POC) and $\mathrm{N}$ (PON) concentrations were determined using seston collected on GF/F filters and a 2400 Series II CHN (carbon, hydrogen, nitrogen) Analyzer (Perkin Elmer). Chlorophyll a (chl a) was extracted from filtered material using a tissue grinder and acetone, and measured with a fluorometer configured with narrow band pass excitation and emission filters. Phytoplankton productivity (PP) was determined using ${ }^{14} \mathrm{C}$-bicarbonate uptake in light and dark bottles under a variable irradiance system.

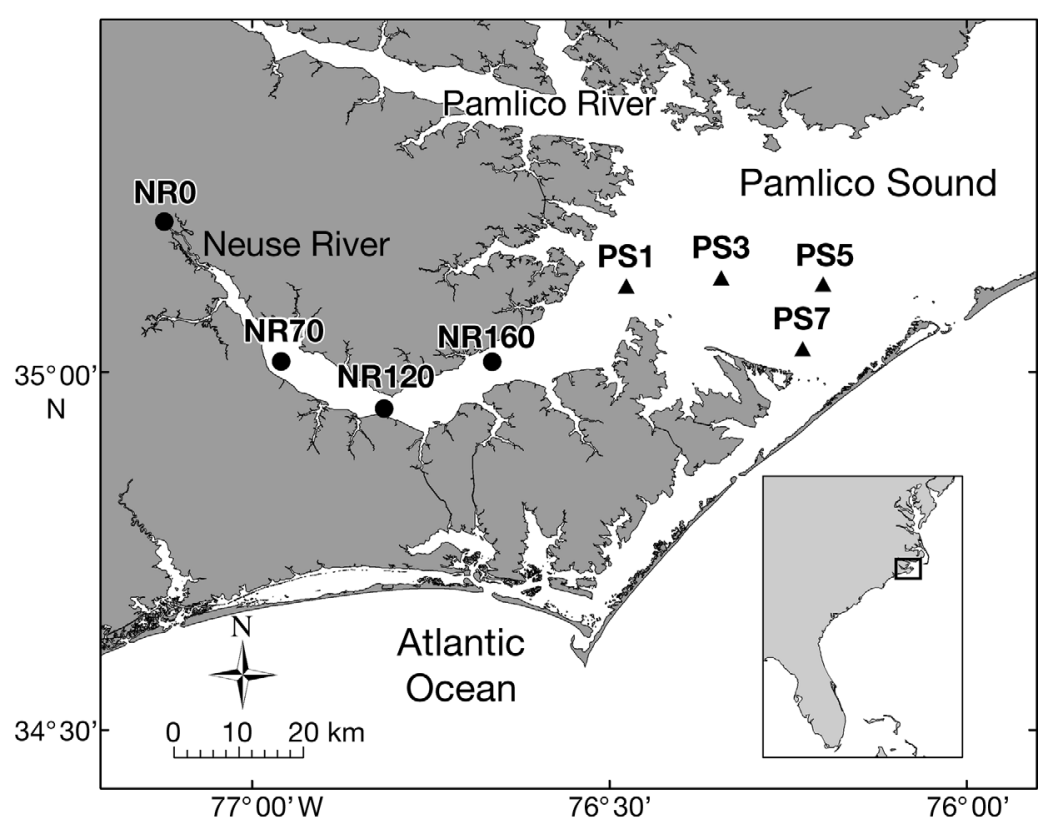

Fig. 1. Study area showing station locations. Station labels are prefixed with, the station group indicator NR (Neuse River, $\bullet$ ) or PS (Pamlico Sound, $\mathbf{\Delta}$ ). Inset shows the extent of the map in context with the southeastern USA 
Bacterioplankton. Productivity was measured by ${ }^{3} \mathrm{H}$-leucine uptake (Kirchman et al. 1985) using an adaptation of the microcentrifuge-based method of Smith \& Azam (1992). Specific activities of the stock ${ }^{3} \mathrm{H}$-L-leucine $\left(4,5-{ }^{3} \mathrm{H}\right.$, ICN or MP Biomedicals) ranged throughout the study period from 40 to $116 \mathrm{Ci} \mathrm{mmol}^{-1}$. Incubations were done in the dark at in situ temperatures for $1 \mathrm{~h}$. The samples received a single rinse of $5 \%$ trichloroacetic acid, and were counted on a Beckman LS 6500 scintillation counter using Cytoscint scintillation cocktail (ICN or MP Biomedicals). An ethanol rinse was not used, since testing showed little non-specific labeling. Samples collected after September 2004 received a base addition step to facilitate protein dissolution and incorporation into the cocktail (Kirschner \& Velimirov 1999). For these samples, $100 \mu l 0.5 \mathrm{~N} \mathrm{NaOH}$ was added after the rinse step and mixed. After $30 \mathrm{~min}$, $50 \mu \mathrm{l}$ of $0.5 \mathrm{~N} \mathrm{HCl}$ was added to neutralize and prevent cocktail gelling. This technique produced rates that were $23 \%$ higher on average, but no attempt was made to correct samples without the addition.

Initial studies determined that leucine uptake appeared saturated at leucine concentrations of about $20 \mathrm{nmol} \mathrm{l^{-1 }}$. A series of 44 kinetic experiments during the study determined that this concentration did not always produce saturated uptake, as has been shown elsewhere (Riemann \& Azam 1992). Maximum uptake rates $\left(V_{\max }\right)$ were calculated by non-linear regression fits of the experimental data to the Michaelis-Menten model (Riemann \& Azam 1992). The ratio of $V_{\max }$ to measured uptake rate was taken to be the isotope dilu- tion factor (ID). The non-linear fit of ID versus leucine concentration for all the experimental replicates was used to calculate $V_{\max }$ for the estuarine data set. In situ BP was calculated using the estimated $V_{\max }$ following Kirchman (2001).

Statistical analysis. Correlations were done using the non-parametric Spearman's rank correlation test ( $\rho=$ coefficient reported). The non-parametric KruskalWallis rank sum test was used for 1-way grouped data comparisons. Simple and multiple linear regressions were used to test relationships between BP and environmental factors. The multiple regression models were compared and selected by the minimization of Akaike's information criterion (AIC) between nested models. All variables except temperature were natural log-transformed before regression analysis to meet the assumption of normality and homoscedasticity. A significance level of $\alpha=0.05$ was chosen for all tests. All analysis and plotting was done using S-Plus version 7.0 (Insightful).

\section{RESULTS}

\section{Data summaries}

A total of 109 trips were made to the NRPS system during 2002 to 2005, resulting in 428 separate water samples. Summarized environmental variables from collected surface water samples are shown in Table 1. Temperature median and range mirrored local climate

Table 1. Summary of surface physical, chemical and biological variables measured during 2002-2005 in the Neuse River and Pamlico Sound estuarine system. IQR: interquartile range (third quartile minus first quartile); n: number of samples. $\mathrm{p}$-values are the probabilities from the Kruskal-Wallis rank sum test for 1-way group comparisons by Year or Season. DOC: dissolved organic carbon; DON: dissolved organic nitrogen; DIN: dissolved inorganic nitrogen; DIP: dissolved inorganic phosphorus; POC: particulate organic carbon; PON: particulate organic nitrogen; PP: phytoplankton productivity; BP: bacteroplankton productivity. BD: below detection (reported as method detection limit/3, DIN: 0.14, Phosphate: 0.004)

\begin{tabular}{|c|c|c|c|c|c|c|}
\hline Variable & Median & IQR & Min-Max & $\mathrm{n}$ & $\mathrm{p}$ (Season) & $\mathrm{p}$ (Year) \\
\hline Temperature $\left({ }^{\circ} \mathrm{C}\right)$ & 20.8 & 12.6 & $3.4-33.6$ & 426 & $<0.001$ & 0.093 \\
\hline Discharge $\left(\mathrm{m}^{3} \mathrm{~s}^{-1}\right)$ & 85.5 & 64.1 & $9.6-507$ & 1461 & $<0.001$ & $<0.001$ \\
\hline Salinity & 7.7 & 13.5 & $0.0-29.2$ & 428 & $<0.001$ & $<0.001$ \\
\hline $\mathrm{DOC}\left(\mu \mathrm{mol} \mathrm{l^{-1 }}\right)$ & 519.3 & 207.5 & $224.9-1368$ & 422 & 0.014 & $<0.001$ \\
\hline $\mathrm{DON}\left(\mu \mathrm{mol} \mathrm{l^{-1 }}\right)$ & 21.9 & 7.6 & 6.1-73.4 & 421 & $<0.001$ & $<0.001$ \\
\hline DOC:DON & 23.9 & 7.8 & $7.2-91.5$ & 417 & $<0.001$ & $<0.001$ \\
\hline $\mathrm{DIN}\left(\mu \mathrm{mol} \mathrm{l^{-1 }}\right)$ & 1.3 & 17.6 & $\mathrm{BD}-60.4$ & 426 & 0.099 & $<0.001$ \\
\hline Phosphate $\left(\mu \mathrm{mol} \mathrm{l}{ }^{-1}\right)$ & 0.4 & 0.8 & $\mathrm{BD}-4.4$ & 422 & $<0.001$ & 0.084 \\
\hline DIN:DIP & 8.9 & 30.6 & $0.1-530$ & 422 & $<0.001$ & 0.27 \\
\hline POC $\left(\mu \mathrm{mol} \mathrm{l} l^{-1}\right)$ & 111.7 & 80.6 & $13.2-1026$ & 426 & 0.35 & 0.35 \\
\hline PON $\left(\mu \mathrm{mol} \mathrm{l}^{-1}\right)$ & 16.7 & 11.8 & $1.4-173$ & 420 & 0.62 & 0.22 \\
\hline POC:PON & 7.2 & 1.8 & $2.0-32.4$ & 420 & $<0.001$ & $<0.001$ \\
\hline DOC:POC & 4.4 & 3.5 & $0.5-40.5$ & 422 & 0.030 & $<0.001$ \\
\hline Chl a $\left(\mu g \mathrm{l}^{-1}\right)$ & 12.8 & 15.8 & $0.3-419$ & 426 & 0.72 & 0.014 \\
\hline$P P\left(\mu g C l^{-1} h^{-1}\right)$ & 23.1 & 35.4 & $0.3-255.7$ & 425 & 0.48 & 0.27 \\
\hline $\mathrm{BP}\left(\mu \mathrm{g} \mathrm{C} \mathrm{l}^{-1} \mathrm{~h}^{-1}\right)$ & 1.9 & 2.5 & $0.1-20.2$ & 428 & $<0.001$ & $<0.001$ \\
\hline
\end{tabular}


conditions, typical for a mid-Atlantic coast estuary. Salinity ranged from freshwater to almost full seawater, reflecting the geographical span of station locations (Fig. 1). Dissolved organic matter (DOM) was abundant (DOC and DON median concentrations were 519 and $22 \mu \mathrm{mol} \mathrm{^{-1 }}$, respectively) and carbon-rich when compared to the Redfield C:N ratio (6.6) or reported bacterial C:N ratios (5.9 to 6.8, Fukuda et al. 1998). The median DIN concentration was slightly greater than $1 \mu \mathrm{mol} \mathrm{l}^{-1}$ and DIN data showed high variability (interquartile range [IQR] and span) due to the large variation in nitrate + nitrite. Phosphate concentrations were less variable than DIN and typically less than $1 \mu \mathrm{mol} \mathrm{l}^{-1}$. The median inorganic $\mathrm{N}$ :P ratio was less than the molar Redfield ratio (16), but because of high variability, measured ratios were often higher than 16. Concentrations of POC were lower and less variable than DOC concentrations, while PON concentrations were of similar magnitude and variability to DON concentrations. This produced particulate C:N ratios that were often close to the Redfield ratio. For total organic matter, the summarized DOC:POC ratios indicate that the dissolved fraction was often the dominant form.

Biological variables are also summarized in Table 1. Median chl a concentration, a proxy for autotrophic biomass, was almost $13 \mu \mathrm{g} \mathrm{l^{-1 }}$ with a peak of over $400 \mathrm{\mu g} \mathrm{l}^{-1}$ (Table 1). About $9 \%$ of the samples had concentrations greater than $40 \mu \mathrm{g}^{-1}$, which is the water quality standard used by the North Carolina Department of Environment and Natural Resources, Division of Water Quality, for establishing the total maximum daily load (TMDL) for total N (h2o.enr.state.nc.us/ tmdl/Docs_TMDL/Neuse TN TMDL II.pdf). The median rate of PP was about $23 \mu \mathrm{g} \mathrm{Cl}^{-1} \mathrm{~h}^{-1}$ with a peak greater than $250 \mu \mathrm{g} \mathrm{C}^{-1} \mathrm{~h}^{-1}$. Both chl a and PP ranged over 3 orders of magnitude. Median BP was about $10 \%$ of median PP and ranged over 2 orders of magnitude, from 0.1 to over $20 \mu \mathrm{g} \mathrm{C} \mathrm{l}^{-1} \mathrm{~h}^{-1}$. Despite that range, BP variability was moderate and $75 \%$ of the measured

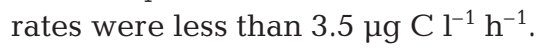

\section{Temporal patterns}

During the 4 yr of the study, BP exhibited clear seasonality that paralleled temperature (Fig. 2). In fact, temperature and BP were strongly and positively correlated (Table 2). River discharge seemed to have little to no effect on the temporal pattern of BP, even though the system experienced the extremes of below and above normal discharge in 2002 and 2003, respectively (Fig. 2). Discharge did show a weak negative correlation with BP (Table 2). Peak BP rates were measured within $4 \mathrm{~d}$ of Category 2 Hurricane Isabel crossing the system on 18 September 2003. Storm surges as high as $3 \mathrm{~m}$ above normal were recorded along the Neuse River shoreline, causing severe flooding in low lying areas. Rates of BP decreased within 2 wk after the hurricane.

The temporal patterns for other environmental variables rarely matched the seasonality in BP. For example, the pattern of PON concentration was fairly uniform with time (Fig. 2) and yielded no difference when grouped by season (Table 1). Since PON was strongly correlated with the other particulate variables, including POC, chl $a$, and PP ( $\rho=0.70$ to $0.83, \mathrm{p}<0.001$ ), these variables also showed no difference when grouped by season. Dissolved variables had a mix of temporal patterns. DOC (and DON) did show differences by season, but these differences were associated with discharge patterns (Fig. 2). The difference in DIN by season was not significant, although phosphate did show significant group differences. Phosphate was correlated with temperature $(\rho=0.43, p<0.001)$, but still showed only a weak correlation with BP, as was true for many of the other variables (Table 2).

Differences in rainfall during the $4 \mathrm{yr}$ of the study produced marked changes in riverine discharge, one of the main driving factors affecting system variability (Fig. 2). Daily mean discharge for the Neuse River exhibited differences when grouped by season and year (Table 1). The lowest median discharge by year $\left(54.9 \mathrm{~m}^{3} \mathrm{~s}^{-1}\right)$ occurred during the very dry 2002, while 2003, which was wetter than normal, had the highest median discharge $\left(175 \mathrm{~m}^{3} \mathrm{~s}^{-1}\right)$ and the greatest intraannual variability $\left(\mathrm{IQR}=156 \mathrm{~m}^{3} \mathrm{~s}^{-1}\right)$. The interannual variation in discharge produced the inverse temporal pattern in surface salinity, which was also significantly different by year.

Discharge controls the delivery of organic matter and inorganic nutrients to estuarine environments, so microbial and chemical variables were also examined

Table 2. Correlation coefficients for selected variables versus bacterioplankton productivity determined using the Spearman rank correlation test. DOC: dissolved organic carbon; DON: dissolved organic nitrogen; POC: particulate organic carbon; PON: particulate organic nitrogen; PP: phytoplankton productivity

\begin{tabular}{|lrc|}
\hline Variable & $\rho$ & $\mathrm{p}$ \\
\hline Temperature & 0.71 & $<0.001$ \\
Discharge & -0.26 & $<0.001$ \\
DOC & 0.24 & $<0.001$ \\
DON & 0.33 & $<0.001$ \\
Phosphate & 0.35 & $<0.001$ \\
POC & 0.31 & $<0.001$ \\
PON & 0.33 & $<0.001$ \\
Chl $a$ & 0.25 & $<0.001$ \\
PP & 0.26 & $<0.001$ \\
\hline
\end{tabular}




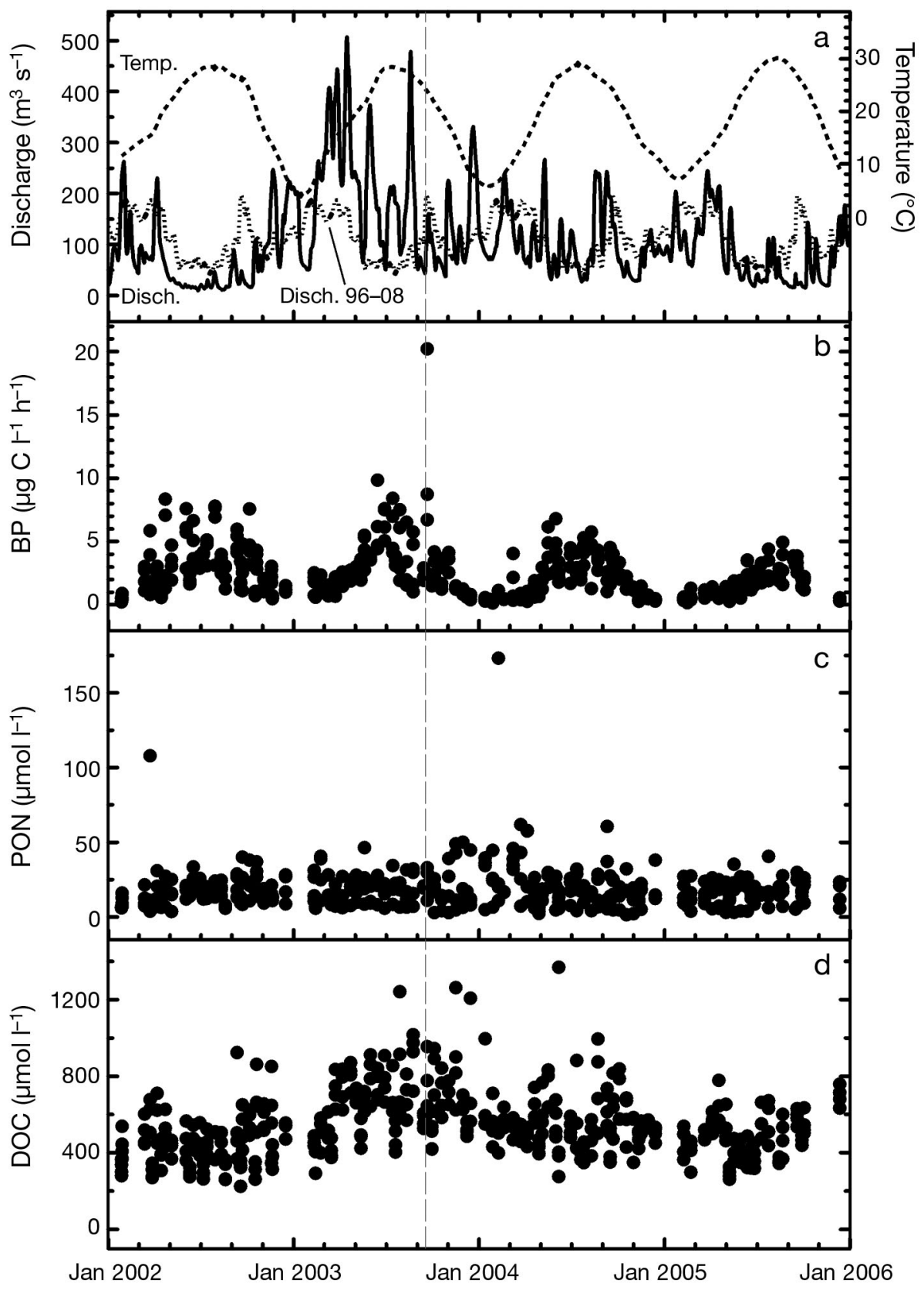

Fig. 2. (a) River discharge, water temperature, (b) surface bacterioplankton productivity (BP), (c) particulate organic nitrogen (PON) and (d) dissolved organic carbon (DOC) in the Neuse River and Pamlico Sound estuarine system versus date. (a) Dashed line is a smoothed line through the temperature data using a LOESS (locally weighted regression) smoothing function. Solid line is the discharge data, and the dotted line is the 12 yr (1996-2008) mean discharge by day. (b-d) Filled circles are measurements at individual stations. Grey vertical dashed line indicates passage of Hurricane Isabel

at the interannual scale. Data for BP showed significant differences when grouped by year (Table 1), but the pattern differed from that for discharge. The abrupt change between 2002 and 2003 seen in the discharge data was not evident for BP. Median BP decreased continuously across the 4 yr from 2.6 in 2002 to 1.4 in 2005. No difference was evident in PP or particulate organic matter (POM) grouped by year, although the particulate $\mathrm{C}: \mathrm{N}$ ratio did show some interannual difference. The pattern for DOC concentration paralleled the interannual discharge pattern and showed a significant difference by year. Chl a and DON also varied significantly by year and had interannual patterns similar to discharge. 


\section{Controlling factors}

The rates of many biochemical processes show an exponential response to temperature, and this relationship is often broadly applied to microbial communities (Apple et al. 2006). The relationship is typically linearized by converting to a log-linear form. The linear regression of natural log-transformed BP versus temperature was highly significant and the model explained $53 \%$ of the variation in BP (Fig. 3). There was no evidence for any threshold in the temperature effect, unlike the data collected by Apple et al. (2006) and others. Removing the post-hurricane trip data caused no significant change in the overall regression slope. The slope of the regression line can be used to estimate the ecological temperature coefficient, $\mathrm{Q}_{10}$, by the relation $Q_{10}=e^{(\text {slope } \times 10)}$. For the temperature range encompassed by this data set, $\mathrm{Q}_{10}$ was 2.35 (95\% CI: 2.17 to 2.53 ).

A similar way to represent the effect of temperature on metabolic rate is using the Arrhenius formulation, rate $=e^{(-\mathrm{E} / k \mathrm{kT})}$, where $\mathrm{E}$ is the activation energy $(\mathrm{eV}), k$ is the Boltzmann constant $\left(8.617343 \times 10^{-5} \mathrm{eV} \mathrm{K}^{-1}\right)$, and $T$ is absolute temperature (Brown et al. 2004). As discussed in the metabolic theory of ecology (MTE) literature, it is predicted that natural log-transformed, masscorrected metabolic rates will be a linear function of the inverse of temperature times the Boltzmann constant and will yield a slope that is the activation energy of the process (Gillooly et al. 2001). Using the data from the present study and assuming that the volumetric BP and PP are mass corrected, the calculated activation energy was $0.63 \mathrm{eV}$ (95\% CI: 0.57 to 0.68 ) for BP and $0.16 \mathrm{eV}$ (95\% CI: 0.05 to 0.27 ) for PP. Gillooly et al.

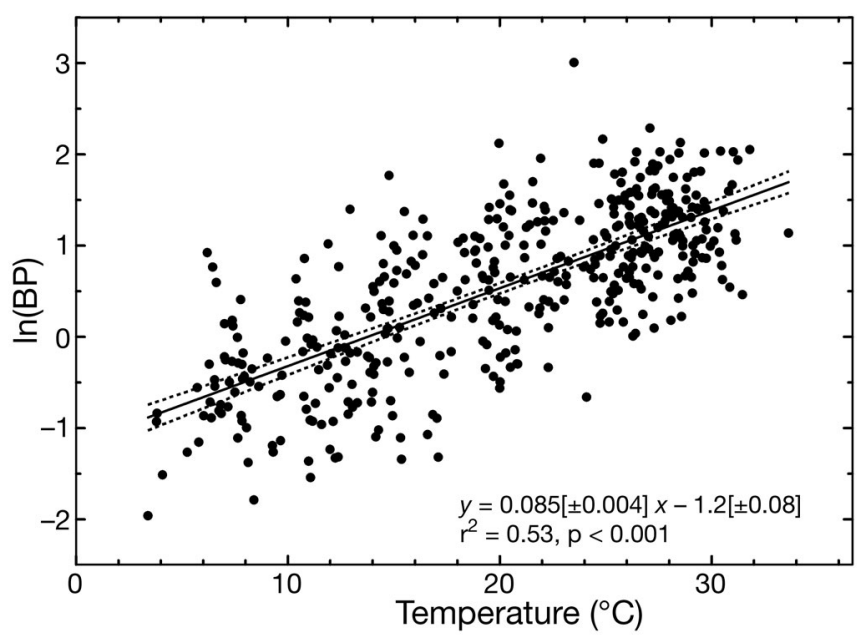

Fig. 3. Linear regression of natural log-transformed surface bacterioplankton productivity (BP) versus temperature. Solid line is the least squares regression and dashed lines are the $95 \%$ confidence limits for the regression. Coefficient standard errors are bound by brackets in the equation. $\mathrm{n}=426$
(2001) reported a mean activation energy of $0.62 \mathrm{eV}$ for a wide variety of organisms ranging from microbes to mammals.

Analysis of covariance (ANCOVA) was used to test if the effect of temperature on BP was universal through space and time. The partial $F$-test of the interaction between the categorical variables and the covariate (temperature) examines the differences in group regression slopes, while the category comparison alone tests for significant differences in regression intercepts, assuming parallel lines. No difference was found in the BP-temperature slopes when grouped by individual station, year or season, although the regression intercepts were different by station and year (Table 3). When the stations were grouped into freshwater (NR0) and brackish (all others), the regression slopes were different. The difference was only between the freshwater station and the others, even when the brackish group was subdivided into Neuse and Pamlico stations. Repeating the regression analysis on the data grouped into freshwater and brackish stations revealed the significantly lower slope and coefficient of determination for the freshwater station (Fig. 4)

Multiple regression analysis was used to determine what variables might improve the BP versus temperature relationship. First, the environmental variables were selected based on the strength of correlations with the residuals of the grouped and ungrouped BP-temperature regressions (Table 4). In many cases the correlations were strengthened compared to the correlations with BP (Table 2). Also notable was the difference in the correlations between station groups. For instance, DOC was more strongly correlated to temperature-corrected BP at the freshwater station than at the brackish stations; the opposite was true for POM (Table 4). Chl a was negatively correlated to the residuals at the freshwater station, but positively correlated at the brackish station group.

Table 3. Results of ANCOVA on $\ln (\mathrm{BP})$ using temperature as the covariate and different categorical variables (BP: bacterioplankton productivity). Stations were considered separately and grouped into freshwater (NR0), brackish (all others), NR (Neuse except NR0) and PS (Pamlico). Season is defined by month $($ Spring $=$ Mar, Apr, May)

\begin{tabular}{|lccc}
\hline \multirow{2}{*}{$\begin{array}{l}\text { Categorical } \\
\text { variable }\end{array}$} & \multicolumn{3}{c}{ Partial F-test p-value } \\
\cline { 2 - 4 } & Category & Interaction & Adjusted $\mathrm{r}^{2}$ \\
\hline Stations & & & \\
All & $<0.001$ & 0.11 & 0.62 \\
Fresh, Brackish & 0.48 & 0.0040 & 0.54 \\
Fresh, NR, PS & $<0.001$ & 0.0064 & 0.61 \\
Year & $<0.001$ & 0.15 & 0.63 \\
Season & 0.50 & 0.12 & 0.53 \\
\hline
\end{tabular}




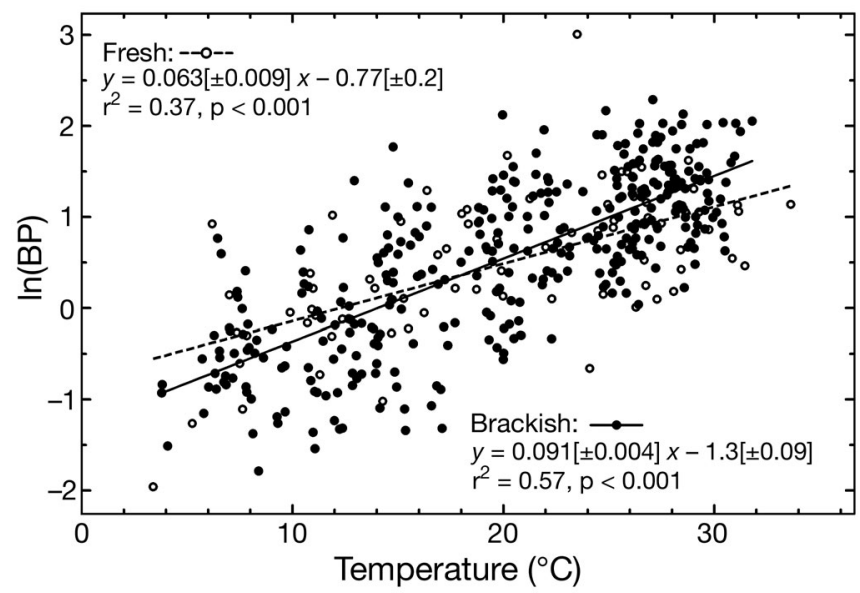

Fig. 4. Linear regression of $\ln$ (bacterioplankton productivity) and temperature as in Fig. 3, but divided into freshwater (NR0) and brackish (all others) stations. Regression confidence limits are omitted. $\mathrm{n}=79$ and 347 for brackish and freshwater stations, respectively

The multiple regression models were then selected using combinations of variables that minimized AIC upon addition or deletion of terms. All of the examined models had temperature and DOC as predictor variables (Table 5). The best selected model for all stations combined included PON and chl $a$ and explained $63 \%$ of the variation in BP (Model 1c). The best freshwater station model had POC and chl $a$ as predictor variables (Model 3c), but less of the total variation was explained. For both the freshwater station and all stations combined, the chl a coefficient was negative. That means when all else is held constant, increases in chl $a$ would yield lower BP rates. At best, two-thirds of the variation in BP was explained in the model for the brackish station group using just temperature, DOC, and PON (Model 2b). Because many of the variables are co-correlated, other variable combinations produced similar model results as long as there was a DOM and POM term present (including PP).
Table 4. Correlation coefficients for selected variables versus the residuals of the $\ln (\mathrm{BP})$ versus temperature regression by station grouping, determined using the Spearman rank correlation test (BP: bacterioplankton productivity). Station groupings as in Table 3. DOC: dissolved organic carbon; DON: dissolved organic nitrogen; POC: particulate organic carbon; PON: particulate organic nitrogen; PP: phytoplankton productivity

\begin{tabular}{|lccc|}
\hline \multirow{2}{*}{ Variable } & \multicolumn{3}{c|}{ Coefficient $(\rho), \mathrm{p}$-value } \\
\cline { 2 - 4 } & All & $\begin{array}{c}\text { Freshwater } \\
\text { stations }\end{array}$ & $\begin{array}{c}\text { Brackish } \\
\text { stations }\end{array}$ \\
\hline Discharge & $0.15,0.002$ & $0.33,0.003$ & $0.11,0.040$ \\
DOC & $0.40,<0.001$ & $0.56,<0.001$ & $0.39,<0.001$ \\
DON & $0.27,<0.001$ & $0.41,<0.001$ & $0.27,<0.001$ \\
Phosphate & $0.09,0.07$ & $0.02,<0.88$ & $0.11,0.049$ \\
POC & $0.35,<0.001$ & $0.25,<0.001$ & $0.42,<0.001$ \\
PON & $0.36,<0.001$ & $0.24,<0.001$ & $0.44,<0.001$ \\
Chl a & $0.31,<0.001$ & $-0.25,0.025$ & $0.46,<0.001$ \\
PP & $0.24,<0.001$ & $-0.22,0.052$ & $0.37,<0.001$ \\
\hline
\end{tabular}

\section{DISCUSSION}

The NRPS makes up a large portion of the Albemarle-Pamlico estuarine system, the largest lagoonal estuary and second largest estuarine complex in the USA. Circulation in this shallow, partially mixed system is driven primarily by wind and river discharge because the bounding barrier islands limit the oceanic connection (Luettich et al. 2002). This creates generally long residence times that facilitate the microbial utilization and processing of excess watershed nutrients and organic matter, the result of anthropogenic enrichment and perturbation (Paerl et al. 1998, 2006b). The range of environmental and biological conditions measured during the course of the present study was typical for this and other temperate estuaries (Day et al. 1989, Paerl et al. 1998, Peierls et al. 2003). The presence of substantial organic matter, much of it dissolved, and an abundant and active autotrophic community together help characterize the NRPS estuary as meso- to eutrophic.

Table 5. Multiple regression model results with $\ln (\mathrm{BP})$ as the response variable (BP: bacterioplankton productivity). Station groupings as in Table 3. All variables except temperature $(T)$ were natural log-transformed. Adjusted $\mathrm{r}^{2}$ is the coefficient of determination adjusted for the number of predictor variables. AIC: Akaike's information criterion; n: number of samples; DOC: dissolved organic carbon; PON: particulate organic nitrogen; POC: particulate organic carbon

\begin{tabular}{|c|c|c|c|c|c|c|c|}
\hline Model & Stations & Variables & Intercept & Coefficients & Adjusted $\mathrm{r}^{2}$ & AIC & $\mathrm{n}$ \\
\hline $1 \mathrm{a}$ & All & T, DOC & -5.8 & $0.086,0.75$ & 0.59 & 712 & 422 \\
\hline $1 b$ & All & $\mathrm{T}, \mathrm{DOC}, \mathrm{PON}$ & -5.9 & $0.084,0.65,0.27$ & 0.63 & 668 & 417 \\
\hline $1 \mathrm{c}$ & All & $\mathrm{T}, \mathrm{DOC}, \mathrm{PON}, \mathrm{chl} a$ & -6.2 & $0.085,0.65,0.45,-0.13$ & 0.63 & 661 & 417 \\
\hline $2 \mathrm{a}$ & Brackish & $\mathrm{T}, \mathrm{DOC}$ & -5.7 & $0.092,0.71$ & 0.63 & 568 & 345 \\
\hline $2 b$ & Brackish & T, DOC, PON & -5.3 & $0.090,0.46,0.40$ & 0.67 & 519 & 342 \\
\hline 3a & Freshwater & $\mathrm{T}, \mathrm{DOC}$ & -8.1 & $0.060,1.2$ & 0.52 & 133 & 77 \\
\hline $3 b$ & Freshwater & $\mathrm{T}, \mathrm{DOC}, \mathrm{POC}$ & -8.9 & $0.059,1.1,0.32$ & 0.54 & 130 & 77 \\
\hline $3 \mathrm{c}$ & Freshwater & $\mathrm{T}, \mathrm{DOC}, \mathrm{POC}, \mathrm{chl} a$ & -7.8 & $0.064,0.76,0.57,-0.17$ & 0.56 & 128 & 77 \\
\hline
\end{tabular}


Rates of BP measured in the NRPS system were compared to other systems and spanned the average range of BP in both global and temperate estuaries reported by Ducklow \& Shiah (1993). Few of the studies in the Ducklow \& Shiah (1993) review used leucine uptake for BP measurement, but this method has become more popular in recent years (Pace et al. 2004). An earlier review (White et al. 1991) and more recent estuarine BP measurements (e.g. Revilla et al. 2000, Apple et al. 2004, Barrera-Alba et al. 2008) confirm that the results from the present study are within the typical range for estuaries.

When examined over time, BP corresponded closely to temperature, supporting the well-documented conclusion that temperature is a major factor controlling bacterioplankton activity (Bott 1975, Shiah \& Ducklow 1994b, Pomeroy \& Wiebe 2001, Apple et al. 2006). The temporal BP pattern did not show a similar correspondence with river discharge, even though there was a weak negative correlation between the two. This was probably a co-correlation with temperature, since discharge tends to be lower in warmer months. The timing of annual peak BP was later in the abnormally wet 2003 as compared with drier years such as 2002 and 2004. This shift may have been from the extreme spring discharge reducing the salinity gradient over the same set of stations, thereby producing similar environmental conditions and less biological variability over the same spatial scale. An extreme case of this was seen in the 1999 floods from Hurricanes Dennis and Floyd, when flood waters extended well into Pamlico Sound (Peierls et al. 2003).

Tropical storms have increasingly impacted the study area since about 1996 (Paerl et al. 2006a), and this higher frequency of storms may continue in the future (Goldenberg et al. 2001, Webster et al. 2005). The 4 major storms that occurred during the study period had varying characteristics that influenced their effect on the system (Paerl et al. 2006a). The only storm that had a noticeable impact on bacterioplankton during the present study was Hurricane Isabel in September 2003. The highest BP value during the $4 \mathrm{yr}$ of study came a few days after Isabel. The high storm surge from Isabel caused severe flooding along the banks of the Neuse River. The return of these flood waters to the river probably brought in enough POM and DOM to stimulate productivity. Sediment resuspension and increased discharge from storms have been documented as being responsible for BP increases (Cotner et al. 2000, Williams et al. 2008). Alternatively, the flood waters may have washed in an allochthonous population of bacteria that were enhanced in the storm-impacted estuary. Either way, the effect was short-lived and BP rates were reduced within $2 \mathrm{wk}$.

When BP was grouped by season, the coherence with temperature was still obvious and the highest rates occurred in the warmest months. The seasonal pattern was not apparent for the other variables, even though many were weakly correlated with BP (Table 2 ). While there were sometimes differences between seasons (e.g. DOC), the lack of seasonality suggests that temperature had limited impact on these factors. This also means that indicators of bacterial resources such as phytoplankton and DOM have only a minor influence on the variation in $\mathrm{BP}$, at least at seasonal and shorter time scales.

The present study spanned 4 yr that differed in precipitation patterns and amounts, particularly between 2002 and 2003. This led to large differences in discharge between those years, which in turn led to differences in nutrient and organic matter loading. Concentrations and, by extension, loading of DOC and DON were significantly different by year and had the highest median in 2003. Phytoplankton biomass mirrored the pattern of discharge with peak median chl a concentration in 2003; PP showed no difference when grouped by years. Given the evidence that BP is a function of phytoplankton biomass and production at broad scales (Cole et al. 1988, White et al. 1991), the interannual patterns of BP and PP or chl a could be expected to show coherence. The rates of BP did differ by year, but differed from discharge in that the medians and spans decreased with time. The BP pattern also did not match the organic matter and phytoplankton patterns. The lack of coherence again suggests that BP is not strongly influenced by phytoplankton, organic matter or discharge at the interannual scale. The lack of interannual and seasonal correspondence between BP and phytoplankton productivity and biomass was not unexpected and has been seen for some other estuarine systems (Findlay et al. 1991, Ducklow \& Shiah 1993, Staroscik \& Smith 2004, Alonso-Sáez et al. 2008). Others report a close coupling between BP and phytoplankton parameters (Cole et al. 1988, Hoch \& Kirchman 1993, Goosen et al. 1997), although the number of studies with multiyear coverage is limited.

It is possible that methodological changes may have caused the decrease in annual BP median and variability. The discovery that the leucine uptake kinetics were not constant led to an increase in experimental leucine concentrations in order to achieve saturation. Higher leucine concentrations could increase the chances of uptake by phytoplankton (Hietanen et al. 2002), but this would only lead to greater BP rates, not the observed decrease. Another change late in the study period was the addition of a base in the leucine processing step to increase counting efficiency. The base addition step only produced slightly higher counts, which again eliminates methodology as the cause of the BP decrease with time. 
The relationship between BP and temperature over time supports the hypothesis that temperature strongly controls bacterial activity. Biochemical processes and, by extension, productivity or growth rates are sensitive to changes in temperature, which can become a limiting factor (Pomeroy \& Wiebe 2001). Microbial metabolism and growth typically show a response represented by $Q_{10}$ values of from 2 to 3 at optimum temperatures (Pomeroy \& Wiebe 2001), a range which has become almost canonical. The ecological or apparent (Hoch \& Kirchman 1993) $Q_{10}$ determined for BP in the NRPS $\left(2.35,3\right.$ to $\left.34^{\circ} \mathrm{C}\right)$ was in the middle of that range and temperature explained about half of the variation in BP rates based on the semi-log regression analysis. This was similar to the relationships found in Narragansett Bay (Staroscik \& Smith 2004), Chesapeake Bay (Shiah \& Ducklow 1994a), Massachusetts salt marsh estuaries (Wright \& Coffin 1983) and enrichment mesocosms (Hobbie \& Cole 1984). Using the alternate Arrhenius formulation, the calculated activation energy of $0.63 \mathrm{eV}$ for BP was remarkably similar to the predicted $0.62 \mathrm{eV}$ from Gillooly et al. (2001) and the average of $0.63 \mathrm{eV}$ reported by Brown et al. (2004), lending more support to the MTE predictions. The activation energy for PP $(0.16 \pm 0.11 \mathrm{eV})$ did not match the $0.33 \mathrm{eV}$ reported for terrestrial net primary productivity (Brown et al. 2004), but still indicated the much lower response of photosynthesis to temperature.

The microbial metabolism-temperature relationship in estuarine ecosystems is not always constant over a given range of temperatures. Hoch \& Kirchman (1993) found that for Delaware Bay there was a distinct break and lowered slope in the plot of log-transformed specific growth against temperature at $12^{\circ} \mathrm{C}$. In the Chesapeake Bay and the East China Sea continental shelf, there is evidence that bacterial growth and production are limited only by temperature when temperatures are below $20^{\circ} \mathrm{C}$ (Shiah \& Ducklow 1994a, Shiah et al. 2000). Apple et al. (2006) found a non-linear relationship between log-transformed BP and temperature, both for their study site in Monie Bay, MD, and for a metaanalysis of 9 different estuaries. Their results showed that temperature was a strong controlling factor of BP at lower temperatures, but beyond $\sim 22^{\circ} \mathrm{C}$, BP ceased to change or even decreased with temperature. These findings suggest that above a temperature threshold, some other factor (e.g. growth substrate) becomes limiting and the $\mathrm{BP}$-temperature relationship decreases or becomes insignificant. This is somewhat contrary to the conceptual model of Felip et al. (1996), which predicts a threshold response of growth rate to temperature, but also a lowering of the temperature effect when resource concentrations are high (Revilla et al. 2000).

Other studies have shown BP to be a constant function of temperature. In mesocosm experiments, Hobbie
\& Cole (1984) found $\log (\mathrm{BP})$ to be a linear function of temperature over about a $20^{\circ} \mathrm{C}$ range. Staroscik \& Smith (2004) also failed to find a break in the BPtemperature relationship, concluding that Delaware Bay was not substrate limited in the summer. The NRPS data were examined for any change or threshold in the log-linear plot of BP and temperature, but none was found. The same conclusion that substrates do not limit BP at warm temperatures appears to hold true for the NRPS.

The effect of temperature seemed to remain constant over time; only the intercept of the semi-log regression changed with year, as would have been expected based on the group differences. Across space, however, the temperature effect was not constant. The slope of the BP-temperature regression was lower at the freshwater station than for the other stations combined. This phenomenon has been described for a variety of systems (White et al. 1991, Hoch \& Kirchman 1993), and suggests that other factors may play more of a role in controlling $\mathrm{BP}$ at this location. Both median DOC:POC and DOC:DON ratios were higher at the freshwater station and, given the strong correlation between POC and chl $a$, the higher ratios indicate the organic matter supply may be more allochthonous in origin and perhaps more difficult to utilize. Instead of variation in substrate availability, another possibility for the change in regression slopes is that the freshwater station has a different bacterioplankton community with an inherently different response to temperature (del Giorgio \& Bouvier 2002). Even when divided by station, the separate regressions still lacked a temperature threshold, meaning there was no shift in growth limitation above a certain temperature at any location.

The absence of evidence for substrate limitation diminishes, but does not eliminate, the role substrates play in the control of BP. In the present study, temperature explained about half of the variation in BP, and substrates are certainly still an important factor describing the residual variation as shown by the moderate correlations between organic matter and the regression residuals (Table 4 ). It is interesting that at the brackish stations, the residuals were better correlated with particulate factors, while at the freshwater station the dissolved components had stronger correlations. This could be a function of a community adapted to the total organic matter pools present, since more phytoplankton biomass and productivity (and hence exudation) occurs at the brackish stations than at the estuary head.

Examples of temperature thresholds in the literature support the concept of complex and interactive controls of bacterial metabolism by temperature and substrates (Pomeroy \& Wiebe 2001, Apple et al. 2006). Multiple regression models that included temperature and several 
proxies for bacterial resources were used to examine this interaction in the NRPS. The most parsimonious model identified DOC and PON (or POC) concentrations as important factors in addition to temperature. Concentrations of bulk DOC probably correlate with bioavailable organic substrates, while bulk PON concentrations might correspond to substrates such as phytoplankton exudates or hydrolysates from abiotic particles. A significant proportion of BP was found to be associated with particles based on preliminary centrifugation experiments (data not shown). Chl a also enhanced the regression models for some station groupings; the negative coefficients were probably caused by multicollinearity, but there remains the possibility of an unknown co-correlate or a lag in the response to chl a. At least a third of the variation in BP remains unexplained. The use of bulk organic matter concentrations cannot provide an assessment of the actual substrates used by the bacterioplankton and leads to less predictive power. Bacterial biomass has been found to relate to productivity (Cole et al. 1988, White et al. 1991), although no relationship was found between BP and abundance in the NRPS using an incomplete data set from the same study (data not shown). Other top-down factors, such as grazing and viral lysis (Noble \& Fuhrman 2000), may play an important role in controlling activity, but these were beyond the scope of the present study.

The temporal patterns of BP in the NRPS revealed the predicted positive effect of temperature on bacterioplankton metabolism. No threshold in this relationship was found, suggesting a lack of substrate limitation at higher temperatures, unlike what has been found in other estuaries. The productive nature of this system may explain this absence of limitation. Control by temperature varied over space, with the freshwater station having a lower temperature effect. This could be due to a different community or different resource availability or a combination of both. The addition of POM and DOM to temperature improved the predictive capabilities of regression models, but at least a third of the variation in BP remains unknown. Some of the unexplained variation could be a function of the inherently complex nature of estuaries, including the impact of stochastic events such as storms and droughts and the bioavailability of local resources. Further research that includes examining these impacts as well as experimental studies on bottom-up controls will help refine understanding of the planktonic microbial community in this estuarine system.

Acknowledgements. Research findings were partially supported by the North Carolina Department of Environment and Natural Resources (ModMon and FerryMon Programs) and the National Science Foundation (Chemical and Biological Oceanography, Ecology of Infectious Diseases, Ecosystem
Studies, and Environmental Engineering and Technology programs). Many technicians and students provided valuable field and laboratory assistance, and we thank in particular J. Braddy, L. A. Cheshire, S. Ensign, K. Howe, L. Kelly, M. Leonard, K. Rossignol, P. Sanderson, C. Tallent, A. Waggener, R. Weaver, V. Wunderly and P. Wyrick. Finally, we greatly appreciate the helpful comments and criticisms from 4 anonymous reviewers.

\section{LITERATURE CITED}

Alonso-Sáez L, Vázquez-Domínguez E, Cardelús C, Pinhassi $\mathrm{J}$ and others (2008) Factors controlling the year-round variability in carbon flux through bacteria in a coastal marine system. Ecosystems 11:397-409

Apple JK, del Giorgio PA, Newell RIE (2004) The effects of system-level nutrient enrichment on bacterioplankton production in a tidally influenced estuary. J Coast Res 45: $110-133$

Apple JK, del Giorgio PA, Kemp WM (2006) Temperature regulation of bacterial production, respiration, and growth efficiency in a temperate salt-marsh estuary. Aquat Microb Ecol 43:243-254

- Barrera-Alba JJ, Gianesella SMF, Moser GAO, SaldanhaCorr'a FMP (2008) Bacterial and phytoplankton dynamics in a sub-tropical estuary. Hydrobiologia 598:229-246

Bott TL (1975) Bacterial growth rates and temperature optima in a stream with a fluctuating thermal regime. Limnol Oceanogr 20:191-197

Brown JH, Gillooly JF, Allen AP, Savage VM, West GB (2004) Toward a metabolic theory of ecology. Ecology 85: 1771-1789

Christian RR, Stanley DW, Daniel DA (1984) Microbiological changes occurring at the freshwater-seawater interface of the Neuse River Estuary, North Carolina. In: Kennedy VS (ed) The estuary as a filter. Academic Press, Orlando, FL, p 349-365

Cole JJ, Findlay S, Pace ML (1988) Bacterial production in fresh and saltwater ecosystems: a cross-system overview. Mar Ecol Prog Ser 43:1-10

Cotner JB, Johengen TH, Biddanda BA (2000) Intense winter heterotrophic production stimulated by benthic resuspension. Limnol Oceanogr 45:1672-1676

Day JW Jr, Hall CAS, Kemp WM, Yáńez-Arancibia A (1989) Estuarine ecology. John Wiley \& Sons, New York, NY

del Giorgio PA, Bouvier TC (2002) Linking the physiologic and phylogenetic successions in free-living bacterial communities along an estuarine salinity gradient. Limnol Oceanogr 47:471-486

Ducklow HW, Shiah FK (1993) Bacterial production in estuaries. In: Ford TE (ed) Aquatic microbiology. Blackwell Scientific Publications, Boston, MA, p 261-287

Felip M, Pace ML, Cole JJ (1996) Regulation of planktonic bacterial growth rates: the effects of temperature and resources. Microb Ecol 31:15-28

Findlay S, Pace ML, Lints D, Cole JJ, Caraco NF, Peierls B (1991) Weak coupling of bacterial and algal production in a heterotrophic ecosystem: the Hudson River estuary. Limnol Oceanogr 36:268-278

> Fukuda R, Ogawa H, Nagata T, Koike I (1998) Direct determination of carbon and nitrogen contents of natural bacterial assemblages in marine environments. Appl Environ Microbiol 64:3352-3358

Gasol JM, Pinhassi J, Alonso-Sáez L, Ducklow H and others (2008) Towards a better understanding of microbial carbon flux in the sea. Aquat Microb Ecol 53:21-38 
Gillooly JF, Brown JH, West GB, Savage VM, Charnov EL (2001) Effects of size and temperature on metabolic rate. Science 293:2248-2251

Goldenberg SB, Landsea CW, Mestas-Nuńez AM, Gray WM (2001) The recent increase in Atlantic hurricane activity: causes and implications. Science 293:474-479

> Goosen NK, van Rijswijk P, Kromkamp J, Peene J (1997) Regulation of annual variation in heterotrophic bacterial production in the Schelde estuary (SW Netherlands). Aquat Microb Ecol 12:223-232

> Hietanen S, Lehtimäki JM, Tuominen L, Sivonen K, Kuparinen J (2002) Nodularia spp. (Cyanobacteria) incorporate leucine but not thymidine: importance for bacterialproduction measurements. Aquat Microb Ecol 28:99-104

Hobbie JE, Cole JJ (1984) Response of a detrital foodweb to eutrophication. Bull Mar Sci 35:357-363

Hoch MP, Kirchman DL (1993) Seasonal and inter-annual variability in bacterial production and biomass in a temperate estuary. Mar Ecol Prog Ser 98:283-295

Kirchman D, K'Nees E, Hodson R (1985) Leucine incorporation and its potential as a measure of protein synthesis by bacteria in natural aquatic systems. Appl Environ Microbiol 49:599-607

Kirchman D (2001) Measuring bacterial biomass production and growth rates from leucine incorporation in natural aquatic environments. In: Paul JH (ed) Marine microbiology. Academic Press, San Diego, CA, p 227-237

Kirschner AKT, Velimirov B (1999) Modification of the ${ }^{3} \mathrm{H}$ leucine centrifugation method for determining bacterial protein synthesis in freshwater samples. Aquat Microb Ecol 17:201-206

Luettich RA Jr, Carr SD, Reynolds-Fleming JV, Fulcher CW, Mcninch JE (2002) Semi-diurnal seiching in a shallow, micro-tidal lagoonal estuary. Cont Shelf Res 22:1669-1681

McManus GB, Griffin PM, Pennock JR (2004) Bacterioplankton abundance and growth in a river-dominated estuary: relationships with temperature and resources. Aquat Microb Ecol 37:23-32

Noble RT, Fuhrman JA (2000) Rapid virus production and removal as measured with fluorescently labeled viruses as tracers. Appl Environ Microbiol 66:3790-3797

Pace ML, del Giorgio P, Fischer D, Condon R, Malcom H (2004) Estimates of bacterial production using the leucine incorporation method are influenced by differences in protein retention of microcentrifuge tubes. Limnol Oceanogr Methods 2:55-61

Paerl HW, Pinckney JL, Fear JM, Peierls BL (1998) Ecosystem responses to internal and watershed organic matter loading: consequences for hypoxia in the eutrophying Neuse River Estuary, North Carolina, USA. Mar Ecol Prog Ser 166:17-25

Paerl HW, Valdes LM, Joyner AR, Peierls BL and others (2006a) Ecological response to hurricane events in the

Editorial responsibility: Hugh Ducklow, Woods Hole, Massachusetts, USA
Pamlico Sound System, North Carolina, and implications for assessment and management in a regime of increased frequency. Estuaries Coasts 29:1033-1045

Paerl HW, Valdes LM, Piehler MF, Stow CA (2006b) Assessing the effects of nutrient management in an estuary experiencing climatic change: the Neuse River Estuary, North Carolina. Environ Manage 37:422-436

Peierls BL, Christian RR, Paerl HW (2003) Water quality and phytoplankton as indicators of hurricane impacts on a large estuarine ecosystem. Estuaries 26:1329-1343

Pomeroy LR, Wiebe WJ (2001) Temperature and substrates as interactive limiting factors for marine heterotrophic bacteria. Aquat Microb Ecol 23:187-204

> Revilla M, Iriarte A, Madariaga I, Orive E (2000) Bacterial and phytoplankton dynamics along a trophic gradient in a shallow temperate estuary. Estuar Coast Shelf Sci 50: 297-313

Riemann B, Azam F (1992) Measurements of bacterial protein synthesis in aquatic environments by means of leucine incorporation. Mar Microb Food Webs 6:91-105

Shiah FK, Ducklow HW (1994a) Temperature and substrate regulation of bacterial abundance, production and specific growth rate in Chesapeake Bay, USA. Mar Ecol Prog Ser 103:297-308

Shiah FK, Ducklow HW (1994b) Temperature regulation of heterotrophic bacterioplankton abundance, production, and specific growth rate in Chesapeake Bay. Limnol Oceanogr 39:1243-1258

> Shiah FK, Gong GC, Chen TY, Chen CC (2000) Temperature dependence of bacterial specific growth rates on the continental shelf of the East China Sea and its potential application in estimating bacterial production. Aquat Microb Ecol 22:155-162

Smith DC, Azam F (1992) A simple, economical method for measuring bacterial protein synthesis rates in seawater using ${ }^{3} \mathrm{H}$-leucine. Mar Microb Food Webs 6:107-114

Staroscik AM, Smith DC (2004) Seasonal patterns in bacterioplankton abundance and production in Narragansett Bay, Rhode Island, USA. Aquat Microb Ecol 35:275-282

Webster PJ, Holland GJ, Curry JA, Change HR (2005) Changes in tropical cyclone number, duration, and intensity in a warming environment. Science 309:1844-1846

White PA, Kalff J, Rasmussen JB, Gasol JM (1991) The effect of temperature and algal biomass on bacterial production and specific growth rate in freshwater and marine habitats. Microb Ecol 21:99-118

Williams CJ, Boyer JN, Jochem FJ (2008) Indirect hurricane effects on resource availability and microbial communities in a subtropical wetland-estuary transition zone. Estuaries Coasts 31:204-214

Wright RT, Coffin RB (1983) Planktonic bacteria in estuaries and coastal waters of northern Massachusetts: spatial and temporal distribution. Mar Ecol Prog Ser 11:205-216

Submitted: September 16, 2009; Accepted: March 1, 2010 Proofs received from author(s): May 11, 2010 